\title{
Teknologia arktisuuden hyödyntämisessä
}

\author{
Liisa Pesonen, Juha Backman, Pasi Suomi, Jussi Nikander ja Markku Koistinen \\ Luke, Vakolantie 55, 03400 Vihti, \\ liisa.pesonen@luke,fi,juha.backman@luke.fi,pasi.suomi@luke.fi,jussi.nikander@luke.fi, \\ markku.koistinen@luke.fi
}

\section{Tiivistelmä}

Arktisen maatalouden kehittämisessä, erikoislaatuisuuden ylläpitämisessä, tuotteistamisessa ja todentamisessa teknologisena haasteena ovat maatilojen monimuotoisuus, vaativat tuotantoprosessit ja olosuhteet sekä moninaiset tekniset osajärjestelmät prosessien hoitamiseen. Uudet Teollisen Internetin teknologiat tuovat potentiaalisia, erilaisiin tuotanto-olosuhteisiin sovellettavia digitaalisuutta ja automaatiota hyödyntäviä ratkaisumalleja arktisuuden hyödyntämisen tukemiseksi maataloudessa. Teollisella Internetillä käsitetään monimutkaisten fyysisten koneiden, sensoriverkkojen ja ohjelmistojen integraatiota. Se hyödyntää koneoppimista, big dataa, esineiden Internetiä, koneidenvälistä viestintää sekä kyber-fyysisiä järjestelmiä, käsitelläkseen ja analysoidakseen konedataa toimenpiteiden säätämistä varten, usein tosiaikaisesti. Teollisen Internetin ratkaisuja voidaan potentiaalisesti hyödyntää seuraavissa kohteissa:

1. Tarkkaa paikkaan ja aikaan sidotun tuotannon prosessidatan dokumentointi prosesseihin liitettävien rätälöityjen sensoriverkkojen, tallentimien ja pilvipalveluiden avulla. Näin tuotantoprosessista kerätään dataa monitorointia sekä jäljitettävyys- ja muun tuotetiedon koostamista ja jakelua varten juuri niistä tekijöistä, joita asiakas ja markkina arvostavat, kuten eläinten hyvinvoinnista, lannoitteiden ja kasvinsuojeluaineiden täsmäkäytöstä, uusiutuvan energian osuudesta tuotannossa, hiilineutraalisuudesta sekä ympäristövaikutuksesta.

2. Tuotantoprosessien säätäminen uuden teknologian avulla resurssitehokkaasti paikka- tai yksilökohtaisen vaihtelun ja kulloistenkin olosuhdetietojen sekä vallitsevien säädösten ja tuotantosopimusten mukaan. Säädön syötedata saadaan sensoriverkoista sekä erilaisista tilan sisäisistä ja ulkoisista datavarastoista ja -palveluista. Säätö edellyttää tietämyksen valjastamista konekielisiksi tietämysmalleiksi koneautomaation päätöksenteon käyttöön. Tuotantoprosessikohtaista tietämystä voidaan kasvattaa hyödyntämällä big data -teknologiaa, muun muassa tiedon aktiivista louhintaa kerätystä prosessi- ja olosuhdedatasta. Kasvitautipainemallit paikkakohtaiseen ruiskutustarpeen määrittämiseen ovat esimerkkejä viljelijöiden käytössä olevista reaaliaikaisista tietämysmalleihin perustuvista sovelluksista. Tällaisella täsmäteknologialla voidaan edistää panosten käytön tehokkuutta paitsi kustannusten säästämiseksi ja sadon laadun turvaamiseksi, myös maaperän, diversiteetin ja vesien laadun suojelemiseksi.

3. Robottien integrointi maatilan järjestelmiin kustannustehokkaasti. Mielenkiintoinen robotiikan sovellus arktisen maataloustuotannon kannalta on robottien käyttäminen pelto- ja avomaanviljelyssä kustannustehokkaaseen mekaaniseen rikkakasvien torjuntaan, kemikaalien sijaan. Koneiden lisääntyvät autonomiset ominaisuudet säästävät työtä ja keventävät työntekijän kuormitusta lisäten tuotannon sosiaalista kestävyyttä.

4. Viljelijöiden keskinäisen luottamuksen vahvistaminen heidän antaessaan toisilleen oikeudet seurata valittujen työ- ja tuotantoprosessiensa kulkua koneiden ja laitteiden välisen tiedonsiirron ja siihen perustuvan etämonitoroinnin avulla. Yhteinen monitorointi edistää koneiden, työpanosten ja peltojen tehokasta yhteiskäyttöä sekä toinen toisiltaan oppimista. Viljelijät voivat yhdenmukaistaa tuotantotapojaan markkinakysynnän mukaan tuottaakseen yhteistyössä riittävän suuren, dokumentoidusti kysyttyä laatua olevan tuote-erän.

5. Tuotannon avoimuuden lisääminen verkottumalla vastaavasti myös asiakkaiden, tiettyä kuluttajaryhmää edustavan toimijan tai jopa yksittäisten kuluttajien kanssa. Maksavien asiakkaiden toiveet tulevat viljelijöiden tietoon nopeasti ja niihin reagoidaan nykyistä ketterämmin - kestävästi palvellen.

Asiasanat: Arktinen maatalous, teknologia, Teollinen Internet, automaatio, tiedonhallinta, arvoverkot 


\section{Johdanto}

Arktisuuden ruoantuotannolle tuomien arvojen vaaliminen maataloustuotannossa on haastavaa. Tällaisia arvoja ovat mm. puhtaus, terveys, korkea sisäinen ja hygieeninen laatu, jäljitettävyys, pieni ympäristöjalanjälki, vastuullisuus, kiertotalous ja hiilineutraalius sekä jätteettömyys (Kurppa ym. 2015). Maatalouden tuottamat raaka-aineet luovat pohjan ruoan arvolle. Maatilojen monimuotoisuus on tuotteiden erilaistamisen mahdollistava tuotannon pohja. Samalla tämä tarkoittaa hyvin hajautettua tuotantoa, jolloin myös tuotantoteknologiset tarpeet ovat moninaiset. Tämän johdosta tuotantojärjestelmät ovat hyvin hajautettuja, koostuen mitä erilaisimmista ja hyvin eritavoin keskenään yhteensopivista osajärjestelmistä (Holster, ym., 2011). Kustannustehokkaiden ja käyttäjäystävällisten järjestelmäkokonaisuuksien muodostaminen on vaikeaa ja tarjonta siksi niukkaa. Maataloustuotannon kannattavuus maailmanlaajuisten markkinoiden ehdoilla toimivassa ruoantuotannossa on arktisella alueella haaste $\mathrm{mm}$. alhaisempien satotasojen vuoksi. Siksi arktisen tuotannon mukanaan tuomat arvonlisät olisi voitava realisoida markkinoilla.

\section{Teollinen Internet maataloudessa}

Uudet teknologiat, erityisesti Teollisen Internetin teknologiat tuovat potentiaalisia, erilaisiin tuotantoolosuhteisiin sovellettavia digitaalisuutta ja automaatiota hyödyntäviä ratkaisumalleja arktisuuden hyödyntämisen tukemiseksi maataloudessa. Teollinen Internet on alun perin General Electricin lanseeraama termi, jolla käsitettiin esineiden internetin ja BigDatan mahdollistamaa työtapojen muutosta (Evans ja Annunziata, 2012). Eri aloilla ja eri tahoilla on erilaisia määritelmiä Teollisesta Internetistä. Perustana Teollisessa Internetissä on laitteiden liitettävyys tietoverkkojen avulla. Liitettävyyden avulla osa tuotteen ominaisuuksista voi sijaita tuotteesta erillään, tuotepilvessä. Laitteet voivat myös viestiä keskenään tietoverkkojen välityksellä ja optimoida omaa toimintaansa ulkopuolelta saaman tiedon avulla (Porter ym., 2014). Liitettävyyden edellytyksenä ovat avoimet tiedonsiirtoratkaisut, joiden kustannustehokkuutta haetaan ratkaisujen standardisoinnilla. Teollinen Internet hyödyntää koneoppimista, big dataa, esineiden Internetiä, koneidenvälistä viestintää sekä kyber-fyysisiä järjestelmiä käsitelläkseen ja analysoidakseen konedataa toimenpiteiden säätämistä varten, usein tosiaikaisesti. Teollisen Internetin myötä esineistä, laitteista ja koneista tulee osa Internetiä esineiden kytkeytyessä siihen omien IP-osoitteiden kautta. Esineet voidaan löytää, ja niihin voidaan luoda yhteys sijainnista riippumatta. Samaan aikaan pilviteknologioita hyödynnetään koneissa niiden toimiessa hajautettuina datavarastoina ja sovelluspalvelimina käyttäjälleen tarjoamine sovelluksineen (Kuva 1).

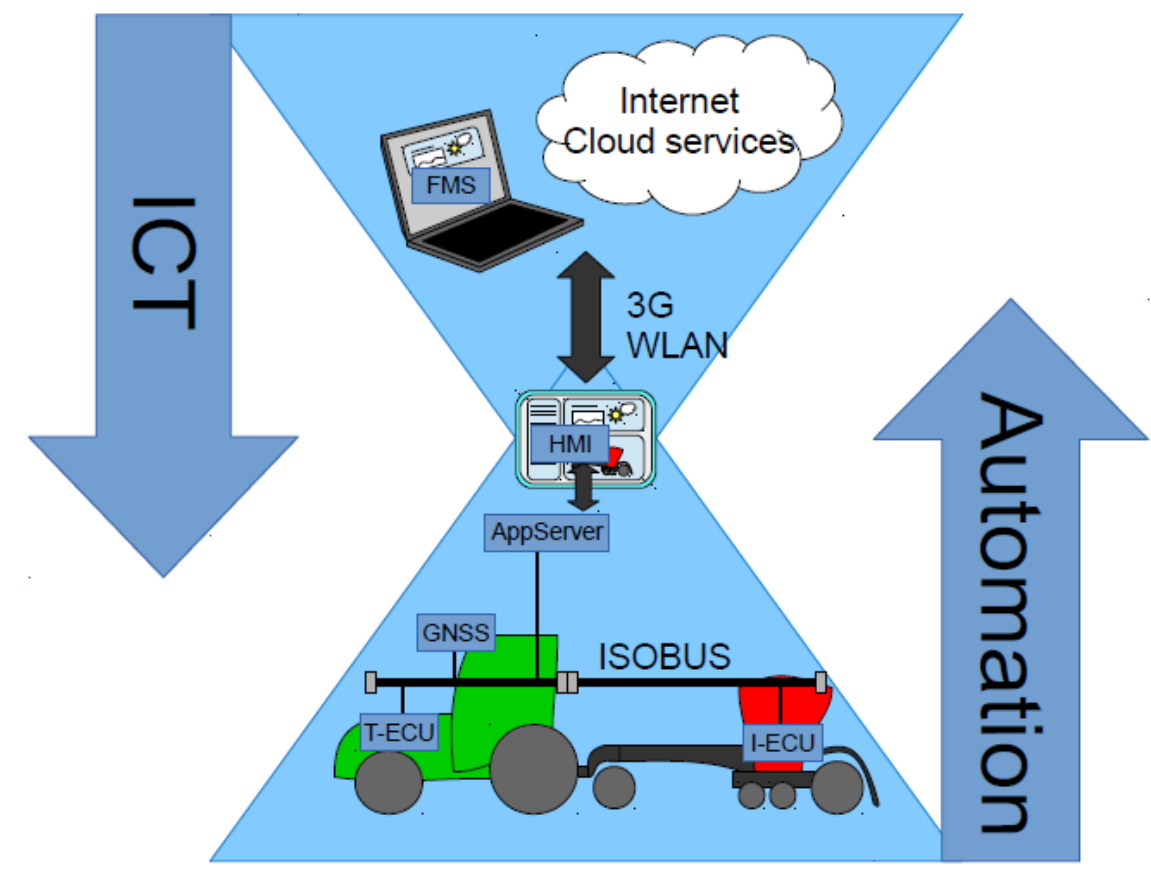

Kuva 1. Teollisen Internetin teknologiat mahdollistavat kokonaisvaltaisen järjestelmäintegraation maataloudessa yhdistämällä koneautomaation ja pilviteknologiat ratkaisut geneerisellä tavalla. (Piirros Juha Backman). 


\section{Uusi teknologia arktisuuden hyödyntämisen tukena}

Teollisen Internetin ratkaisuja voidaan potentiaalisesti hyödyntää muun muassa seuraavissa arktisen maatalouden arvoa tuottavissa ja arvon realisointia markkinoilla tukevissa kohteissa:

\section{Tuotannon arvokomponenttien osoittaminen ja jäljitettävyys}

Tuotannon toteutustiedon dokumentointi tarkkana aikaan ja paikkaan sidottuna prosessidatana. Prosessidata voi koostua esimerkiksi työkoneen tuottamasta koneen säätymisen taltioivasta jatkuvasta datasta, prosessiin liitetystä rääälöidystä sensoriverkon tuottamasta olosuhdedatasta sekä prosessiin syötettyjen panosten, kuten lannoitteiden, polttoaineiden ja työn määrää ja laatua kuvaavasta datasta. Data tallennetaan laiteverkkoon liitettyihin tallentimiin ja esimerkiksi pilvipalveluun, josta se on käytettävissä ja jaettavissa halutuille toimijoille sovitusti (Pesonen, ym., 2013). Näin tuotantoprosessista kerättyä dataa voidaan käyttää paitsi prosessin monitorointiin ja ohjaukseen, myös jäljitettävyystiedon sekä muun tuotetiedon koostamiseen tekijöistä, joita asiakas ja markkinat arvostavat. Tällaista lisäarvoa tuovaa tietoa voisi tyypillisesti olla eläinten hyvinvointia, lannoitteiden ja kasvinsuojeluaineiden täsmäkäyttöä, uusiutuvan energian osuutta tuotannossa, hiilineutraaliutta sekä ympäristövaikutuksia kuvaavat tiedot.

\section{Resurssitehokas ja säädöstenmukainen tuotantotapa}

Tuotantoprosessien, esimerkiksi kylvön, lannoituksen ja kasvinsuojelun valvonta ja säätäminen automaattisesti ja resurssitehokkaasti paikka- tai yksilökohtaisen vaihtelun ja kulloistenkin olosuhdetietojen mukaan. Prosessin (koneen) säädössä voidaan varmentaa vallitsevien säädösten ja tuotantosopimusten mukainen toiminta myös yllättävien tapahtumien, kuten äkillisten sade- ja tuuliolosuhteiden muuttumisen aikana kesken kasvinsuojeluruiskutustehtävän (Pesonen, ym., 2013, Kaivosoja, ym., 2014). olosuhteiden muuttumisen. Säädön syötedata saadaan sensoriverkoista sekä erilaisista tilan sisäisistä ja ulkoisista datavarastoista ja -palveluista.

Säätö edellyttää tietämyksen valjastamista konekielisiksi tietämysmalleiksi koneautomaation päätöksenteon käyttöön. Tuotantoprosessikohtaista tietämystä voidaan kasvattaa hyödyntämällä big data -teknologiaa, muun muassa tiedon aktiivista louhintaa kerätystä prosessi- ja olosuhdedatasta. Kasvitautipainemallit paikkakohtaiseen ruiskutustarpeen määrittämiseen ovat esimerkkejä viljelijöiden käytössä olevista reaaliaikaisista tietämysmalleihin perustuvista sovelluksista (van Maanen ja Xu, 2003, Stocker, 2015). Tällaisella täsmäteknologialla voidaan edistää panosten käytön tehokkuutta paitsi kustannusten säästämiseksi ja sadon laadun turvaamiseksi, myös maaperän, diversiteetin ja vesien laadun suojelemiseksi.

\section{Robottien integrointi maatilan järjestelmiin kustannustehokkaasti}

Mielenkiintoinen robotiikan sovellus arktisen maataloustuotannon kannalta on robottien käyttäminen pelto- ja avomaanviljelyssä kustannustehokkaaseen mekaaniseen rikkakasvien torjuntaan, kemikaalien sijaan. Automaatio ja tarvittava teknologia on kehittynyt mekaanisen rikkakasvien torjunnassa eri osaalueilla jo kaupallisen tuotteen tasolle (Slaughter ym. 2008). Myös täysin automaattisia robottisovelluksia on pilotteina ollut olemassa, mutta kaupallinen läpimurto on vielä saavuttamatta.

Koneiden lisääntyvät autonomiset ominaisuudet säästävät työtä ja keventävät työntekijän kuormitusta lisäten tuotannon sosiaalista kestävyyttä. Robottien avulla on myös mahdollista tehdä sellaisia työoperaatioita, jotka ihmistyönä olisivat mahdottomia.

Robottien yleistymisen esteenä on kuitenkin yleensä tarvittavan infrastruktuurin puuttuminen. Robotti tarvitsee ympärilleen toimivaa järjestelmää, joka tukee toimintaa ja robotin itsenäistä päätöksentekoa. Teollisessa ympäristössä robotit ovat yleistyneet, sillä toiminta on ollut liitettävissä muuhun automaatiojärjestelmään. Maataloussovelluksissa automaatiojärjestelmät ovat kuitenkin vielä hajanaisia ja manuaalista käsin tehtävää tiedonsiirtoa eri järjestelmien välillä on runsaasti. Teollisen Internetin tarjoamat ratkaisut voivat tuoda helpotuksen liitettävyyden ongelmaan ja asteittain tapahtuva automaation ja autonomian tason nosto johtaa lopulta robotteihin. (Backman, 2015)

\section{Viljelijä- ja arvoverkkojen muodostaminen raaka-aineen arktisen arvon realisoimiseksi markkinoilla}

Viljelijöiden keskinäisen luottamuksen vahvistaminen luotettavien tiedonjakelukanavien kautta, eräänlaisten liiketoimintaekosysteemien muodostamiseksi. Luotetuissa ja luottamuksellisissa verkoissa viljelijät ja muuta alkutuotannon toimijat voivat antaa toisilleen oikeudet seurata valittujen työ- ja tuotantoprosessiensa kulkua esimerkiksi koneiden ja laitteiden välisen tiedonsiirron ja siihen perustuvan etämonitoroinnin avulla. Yhteinen monitorointi edistää koneiden, työpanosten ja peltojen tehokasta yhteiskäyttöä sekä toinen toisiltaan oppimista. 
Viljelijät voivat halutessaan yhdenmukaistaa tuotantotapojaan markkinakysynnän mukaan tuottaakseen yhteistyössä riittävän suuren, dokumentoidusti kysyttyä laatua olevan tuote-erän. Luotetussa toimijaverkossa viljelijät voivat luovuttaa tuottamiensa raaka-aine-erien määrä-, laatu-, tuotantotapa- ja sijaintitiedot verkon yhteiseen käyttöön, tavoitteena muodostaa riittävän suuria markkinoilla kysyttyjä erilaatuisia raaka-aine-eriä myyntiin. Huonolaatuisille erille voitaisi etsiä yhdessä esimerkiksi bioenergiakäyttöä. Analogiaa voisi hakea esimerkiksi Biomassa-atlas -hankkeesta (Lehtonen, ym., 2014).

\section{Kuluttajakysynnän ja -toiveiden ketterä huomioonottaminen tuotannossa}

Tuotannon avoimuuden ja aitojen kuluttajatarpeiden tuntemuksen lisääminen alkutuotannossa verkottumalla myös asiakkaiden, tiettyä kuluttajaryhmää edustavan toimijan tai jopa yksittäisten kuluttajien kanssa pilvipalveluja ja sosiaalista mediaa hyödyntäen. Maksavien asiakkaiden toiveet tulevat viljelijöiden tietoon nopeasti ja niihin voidaan reagoida nykyistä ketterämmin. Myös pienimuotoiset kokeilut suoraan kuluttajien kanssa uusien lisäarvotekijöiden markkina-arvon testaamiseksi halutuilla kuluttajaryhmillä olisi mahdollista toteuttaa nopeasti ja kustannustehokkaasti.

Tuotteen ominaisuuksia, esimerkiksi dokumentoituja arktisia vahvuuksia on mahdollista esitellä kuluttajalle paitsi nettipalveluissa myös fyysisissä ostotilanteissa muun muassa tuotepakkauksiin liitettävillä moninaisilla lisätyn todellisuuden teknologioilla. Azuman ym. (2001) mukaan lisätty todellisuus 1) yhdistää todelliset ja virtuaaliset objektit todellisessa ympäristössä, 2) toimii interaktiivisesti ja reaaliaikaisesti 3) kohdistaa todelliset ja virtuaaliset objektit toistensa kanssa.

\section{Johtopäätökset}

Uudet automaatio- ja tiedonhallintateknologiat, ja etenkin geneeriset Teollisen Internetin teknologiat mahdollistavat monenlaisen tuen arktisen maatalouden arvonlisän muodostumiselle läpi tuotantoketjun aina markkinoille ja kuluttajalle saakka. Useat tässä artikkelissa mainituista teknologioista ovat vasta prototyyppiasteella tai niitä on sovellettu maataloustuotannossa ja raaka-aine-erien ja elintarviketuotteiden markkinoinnissa vasta muutamiin kohteisiin. Yhteistä kaikille mainituille sovellusmuodoille on, että niiden perustana ja arvonlisän pohjana on tuotantoprosessista kerätty aikaan ja paikkaan sidottu tuotannon toteutusta kuvaava dokumenttidata. Kertaalleen kerätty data on siis monikäyttöistä ja uusien tiedonhallintateknologioiden ansiosta kustannustehokasta. Parhaimmillaan kuvaillut teknologiat lisäävät maataloustuotannon kannattavuutta ja kilpailukykyä merkittävästi. Teknologioiden monipuolinen ja geneeristen ratkaisujen standardointiin tähtäävä tutkimus ja kehittäminen arktisen maatalouden kontekstissa, sekä laajat pilotoinnit eri mittakaavaisissa arvoverkostoissa nopeuttaisivat kustannustehokkaiden ja käytäntöä parhaiten palvelevien ratkaisujen nopeassa yleistymisessä.

\section{Kirjallisuus}

Azuma, R., Baillot, Y., Behringer, R., Feiner, S., Julier, S. \& MacIntyre, B. 2001. Recent Advances in Augmented Reality. Survey, IEEE Computer Graphics and Applications, November/December 2001, p. 34-47. http://www.cs.unc.edu/ azuma/cga2001.pdf (14.12.2015)

Backman, J. 2015. Kasvintuotantojärjestelmien digitalisaation tiekartta. Luonnonvara- ja biotalouden tutkimus 71/2015, Luonnonvarakeskus, Helsinki

Evans, P.C. \& Annunziata, M. 2012. Industrial internet: Pushing the boundaries of minds and machines. General Electric white paper.

Holster, H., Fusai, B., Giannerini, G., Horakova, S., Martini, D.,Teye, F., \& Ipema, B. 2011. Current situation on data exchange in agriculture in the EU27 \& Switzerland. In E. Gelb, \& K. Charvat (Eds.), Proceedings of EFITA/WCCA'11 conference 11the14th July 2011 (pp. 367e381). Prague, Check Republic.

Kaivosoja, J., Jackenroll, M., Linkolehto, R., Weis, M. \& Gerhards, R. 2014. Automatic control of farming operations based on spatial web services. Computers and Electronics in Agriculture, 100: 110-115.

doi:10.1016/j.compag.2013.11.003

Kurppa, S., Kotro, J., Heikkilä, L., Reinikainen, A., Timonen, K., Peltola, R. \& Manninen, O. 2015. Arktinen ruoantuotanto: taustaselvitys ja kiteytysmatriisi. Luonnonvara- ja biotalouden tutkimus 47/2015. http://urn.fi/URN:ISBN:978-952-326-094-8

Lehtonen, E., Anttila, P., Haapanen, A., Huopana, T., Joensuu, I., Juntunen, R., Kolehmainen, M., Kymenvaara, M., Lehtinen, H., Leskinen, P., Lilja-Rothsten, S., Merilehto, K., Myllymaa, T., Myllyviita, T., Nousiainen, R., Rasi, S., Sikanen, L., Stocker, M. \& Valpola, S. 2014. Biomassa-atlas. Biomassojen kestävän käytön työväline. Esiselvityksen loppuraportti. $\quad$ MTT Raportti $176: \quad 89$ p. http://jukuri.luke.fi/bitstream/handle/10024/485234/mttraportti176.pdf 
Porter, Michael E., \& Heppelmann, J.E. 2014. "How smart, connected products are transforming competition." Harvard Business Review 92 (11): 11-64.

Pesonen, L., Teye, F., Ronkainen, A., Koistinen, M., Kaivosoja, J., Suomi, P. \& Linkolehto, R. 2012. Cropinfra : an internet-based service infrastrcture to support crop production in future farms. Biosystems Engineering, 120: 92-101.

Slaughter, D.C., Giles, D.K., \& Downey, D. 2008. Autonomous robotic weed control systems: A review. Computers and Electronics in Agriculture, 61 (1): 63-78.

Stocker, M. 2015. Situation awareness in Environmental Monitoring. Publications of the University of Eastern Finland. Dissertations in Forestry and Natural Sciences No 192. http://epublications.uef.fi/pub/urn_isbn_978952-61-1908-3/urn_isbn_978-952-61-1908-3.pdf (14.12.2015)

vanMaanen, A. \& Xu, X.-M. 2003. Modelling Plant Disease Epidemics. European Journal of Plant Pathology 109: 669-682. 